\title{
SISTEM PAKAR UNTUK DIAGNOSIS PENYAKIT AYAM YANG DISEBABKAN OLEH VIRUS
}

\author{
Bambang Yuwono \\ Jurusan Teknik Informatika UPN “Veteran” Yogyakarta \\ E-mail : masbayu@walla.com
}

\begin{abstract}
This research based on necessery of a tool which can help for breeder or extension agent in diagnosing disease of chicken livestock which is because of virus. The tool is an expert system which is besides to diagnose, this system is expected able to give the medication suggestion. This Expert system to communicate with the user in the form of question "yes" or "no". Method Inference used backward chaining with the model of Depth first search. Step system development composed : knowledge acquisition, knowledge representation, mechanism inference, input scheme / output and implementation. Output from this tool is name of disease type groaning chicken and its medication suggestion
\end{abstract}

\section{Keyword : chicken disease, expert system, diagnosed, medication}

Penelitian ini dilakukan berdasarkan atas kebutuhan akan adanya alat bantu bagi peternak atau penyuluh dalam mendiagnosis penyakit ternak ayam yang disebabkan oleh virus. Alat bantu tersebut merupakan sistem pakar yang selain untuk mendiagnosis, sistem ini diharapkan mampu memberikan saran-saran pengobatannya. Sistem pakar ini untuk berkomunikasi dengan user berupa pertanyaan "ya" atau "tidak". Metode inferensi yang digunakan adalah Backward chaining dengan model Depth first search. Adapun tahapan pengembangan sistem meliputi : akuisisi pengetahuan, representasi pengetahuan, mekanisme inferensi, perancangan input/output dan implementasi. Keluaran dari perangkat lunak ini adalah nama jenis penyakit yang menyerang ayam dan saran pengobatannya

Kata Kunci : penyakit ayam, sistem pakar, diagnosis, pengobatan

\section{Pendahuluan}

Penyakit pada ternak tidaklah asing lagi bagi peternak, namun ini merupakan kendala yang sering dihadapi peternak. Para peternak kadang tahu kalau ternaknya terserang penyakit, tetapi peternak tidak tahu penyakit apa yang sedang menyerang ternaknya serta bagaimana mengobatinya. Sehingga untuk mengetahui penyakit yang sedang menyerang ternak dibutuhkan seorang penyuluh ternak atau dokter hewan. Namun pada kenyataannya penyuluh atau dokter tidak selalu ada ketika dibutuhkan karena terbatasnya tenaga ahli. Hal ini bila tidak segera ditangani besar kemungkinan ternak yang lain akan tertular sehingga berujung pada kematian.

Para penyuluh ternak juga kesulitan untuk mengidentifikasi jenis penyakit yang menyerang ternak, walaupun terlihat adanya perubahan pada hewan ternak. Bahkan kadangkadang penyuluh tidak tahu cara pengobatannya untuk menyembuhkan penyakit ternak tersebut. Sehingga penyuluh kesulitan dalam memberi penjelasan kepada peternak tentang gejala-gejala (tanda-tanda) ternak sedang diserang penyakit.

Berdasarkan kemajuan dalam bidang komputer dan informatika, kerumitan dan kesulitan dapat ditanggulangi dengan menyediakan suatu perangkat lunak (sistem pakar) berupa program untuk mendiagnosis penyakit yang menyerang ternak ayam dan cara pengobatannya. Pada bidang software atau perangkat lunak, saat ini sedang berkembang suatu teknik untuk mencoba membuat komputer yang mampu menirukan proses pemikiran atau kecerdasan manusia atau istilah umumnya kecerdasan buatan (Artificial Intelligence). Salah satu bidangnya adalah sistem pakar (Expert System) dimana pengetahuan seorang pakar atau beberapa pakar dalam bidang tertentu dituangkan kedalam program komputer, sehingga diharapkan program ini identik seperti seorang pakar sesungguhnya.

Sistem pakar ini bisa membantu dokter dalam mendiagnosa penyakit dan memberi resep atau obat. Hal ini tidak berarti menggantikan kedudukan dokter, tetapi hanya membantu dalam mengkonfirmasikan keputusannya, karena mungkin bisa terdapat banyak alternatif yang harus dipilih secara tepat.

Oleh karena itu untuk menjawab semua kebutuhan di atas, maka penting kiranya dirancang dan dikembangkan sebuah perangkat lunak (sistem pakar) untuk mendiagnosis 
penyakit khususnya ternak ayam. Selain untuk mendiagnosis, sistem ini diharapkan mampu memberikan saran-saran cara pengobatan.

\section{Tinjauan Pustaka}

\subsection{Sistem Pakar}

Secara umum, sistem pakar (Expert System) adalah sistem yang berusaha mengadopsi pengetahuan manusia ke komputer, agar komputer dapat menyelesaikan masalah seperti yang biasa dilakukan oleh para ahli. Sistem pakar yang baik dirancang agar dapat menyelesaikan suatu permasalahan tertentu dengan meniru kerja dari para ahli. Dengan sistem pakar ini, orang awam pun dapat menyelesaikan masalah yang cukup rumit yang sebenarnya hanya dapat diselesaikan dengan bantuan para ahli. Bagi para ahli, sistem pakar ini juga akan membantu aktivitasnya sebagai asisten yang sangat berpengalaman.

Menurut Turban(1995) konsep dasar sistem pakar mengandung keahlian (expertise), pakar (expert), pengalihan keahlian (transfering expertise), inferensi (inferencing), aturan (rules) dan kemampuan menjelaskan (explanation capability).

Keahlian (expertise) adalah suatu kelebihan penguasaan pengetahuan di bidang tertentu yang diperoleh dari pelatihan, membaca atau pengalaman. Pengetahuan tersebut memungkinkan para ahli untuk dapat mengambil keputusan lebih cepat dan lebih baik dari pada seseorang yang bukan ahli.

Pakar (Expert) adalah seseorang yang mampu menjelaskan suatu tanggapan, mempelajari hal-hal baru seputar topik permasalahan (domain), menyusun kembali pengetahuan jika dipandang perlu, memecah aturan-aturan jika dibutuhkan, dan menentukan relevan tidaknya keahlian mereka.

Pengalihan keahlian (transfering expertise) dari para ahli ke komputer untuk kemudian dialihkan lagi ke orang lain yang bukan ahli, hal inilah yang merupakan tujuan utama dari sistem pakar. Proses ini membutuhkan 4 aktivitas yaitu :

1. Tambahan pengetahuan (dari para ahli atau sumber-sumber lainnya)

2. Representasi pengetahuan (ke komputer)

3. Inferensi pengetahuan

4. dan pengalihan pengetahuan ke user.

Pengetahuan yang disimpan di komputer disebut dengan nama basis pengetahuan. Ada dua tipe pengetahuan, yaitu fakta dan prosedur (biasanya berupa aturan).

Salah satu fitur yang harus dimiliki oleh sistem pakar adalah kemampuan untuk menalar, Jika keahlian-keahlian sudah tersimpan sebagai basis pengetahuan dan sudah tersedia program yang mampu mengakses basis data, maka komputer harus dapat diprogram untuk membuat inferensi. Proses inferensi ini dikemas dalam bentuk motor inferensi (inference engine)

Sebagian besar sistem pakar komersial dibuat dalam bentuk rule based systems, yang mana pengetahuan disimpan dalam bentuk aturan-aturan. Aturan tersebut biasanya berbentuk IF-THEN.

Fitur lainnya dari sistem pakar adalah kemampuan untuk memberikan nasehat atau merekomendasi. Kemampuan inilah yang membedakan sistem pakar dengan sistem konvensional.

\subsection{Motor Inferensi}

Mesin inferensi adalah bagian yang mengandung mekanisme fungsi berpikir dan polapola penalaran sistem yang digunakan oleh seorang pakar. Mekanisme ini akan menganalisa suatu masalah tertentu dan selanjutnya akan mencari jawaban atau kesimpulan terbaik.

Ada dua teknik yang dapat dikerjakan dalam melakukan inferensi, yaitu :

1. Forward Chaining

Pencocokan fakta atau pernyataan dimulai dari bagian sebelah kiri (IF dulu). Dengan kata lain, penalaran dimulai dari fakta terlebih dahulu untuk menguji kebenaran hipotesis.

2. Backward Chaining

Pencocokan fakta atau pernyataan dimulai dari bagian sebelah kanan (THEN dulu). Dengan kata lain, penalaran dimulai dari hipotesis terlebih dahulu, dan untuk menguji kebenaran hipotesis tersebut harus dicari fakta-fakta yang ada dalam basis pengetahuan. 
Kedua metode inferensi tersebut dipengaruhi oleh tiga macam penelusuran, yaitu Depth-first search, Breadth-first search dan Best-first search.

a. Breadth-first search, Pencarian dimulai dari simpul akar terus ke level 1 dari kiri ke kanan dalam 1 level sebelum berpindah ke level berikutnya.

b. Depth-first search, Pencarian dimulai dari simpul akar ke level yang lebih tinggi. Proses ini dilakukan terus hingga solusinya ditemukan atau jika menemui jalan buntu.

c. Best-first search, bekerja berdasarkan kombinasi kedua metode sebelumnya.

\subsection{Diagnosis penyakit ayam}

Diagnosis suatu penyakit pada ternak ayam yang telah mati, dapat dilakukan dengan pemeriksaan secara sistematis dan cermat, sehingga dapat diketahui perubahan-perubahan yang terjadi pada ayam. Kita dapat mengetahui secara langsung jenis penyakitnya dan jenis pengobatan terhadap ayam yang masih sehat dengan obat-obatan yang tepat.(Akoso, 1998) Cara mendiagnosis penyakit ayam demikian disebut nekropsi ayam, khususnya pada penyakitpenyakit yang mengakibatkan perubahan karakteristik di dalam tubuh ayam.

Cara nekropsi ayam sering dibutuhkan oleh peternak, sebab diagnosis ini adalah diagnosis lapangan. Bila kurang yakin akan hasil diagnosis, dapat dikuatkan dengan bantuan diagnosis laboratoris. Sifat pemeriksaan nekropsi berdasarkan perubahan anatomis histologis, yang untuk penyakit tertentu diagnosis dapat ditentukan dengan hanya melihat perubahan makroskopis.

Nekropsi harus dilakukan secepat mungkin setelah ayam mati, untuk mencegah terjadinya perubahan setelah kematian. Apabila tidak dapat dilakukan oleh peternak, bangkai ayam dapat disimpan dalam tumpukan es atau tempat yang dingin, untuk mencegah pencemaran.

\section{Metode Penelitian}

Tahap-tahap yang dilakukan dalam penelitian ini disesuaikan dengan tahapan pengembangan sistem pakar yang umum(Harmon \& King, 1985), yaitu :

a. Identifikasi domain dan melakukan analisis terhadap pengetahuan, meliputi akuisisi pengetahuan, representasi pengetahuan dan mekanisme inferensi

b. Perancangan, meliputi perancangan input dan perancangan output

c. Implementasi, yaitu melakukan penulisan program (pengkodean dari tahap perancangan.

\subsection{Akuisisi Pengetahuan (Knowledge Acquisition)}

Proses pengumpulan pengetahuan mengenai diagnosis penyakit ayam ini diperoleh dari seorang pakar (dokter hewan) yang dilengkapi dengan buku-buku mengenai penyakit dan kesehatan ayam. Pengetahuan yang diperoleh meliputi Gejala-gejala yang diderita ayam, jenis penyakit dan cara pengobatannya. Pengetahuan tersebut kemudian direpresentasikan ke basis pengetahuan.

Tabel 1 menunjukkan hubungan antara gejala-gejala yang diderita ayam dan jenis penyakitnya. Matrik tersebut diperoleh berdasarkan pengalaman seorang pakar (dokter hewan) dan juga mengacu pada beberapa literatur.

\subsection{Representasi Basis Pengetahuan}

Dalam penelitian ini basis pengetahuan direpresentasikan dengan menggunakan kaidah produksi, yaitu berupa IF - THEN. Berikut contoh untuk penyakit Tetelo.

$\begin{array}{ll}\text { IF } & \text { produksi telur turun } \\ \text { AND } & \text { batuk } \\ \text { AND } & \text { ayam lesu serta lemah } \\ \text { AND } & \text { nafsu makan berkurang } \\ \text { AND } & \text { kelumpuhan pada sayap dan kaki } \\ \text { AND } & \text { bersih } \\ \text { AND } & \text { berat telur turun dan ukuran tidak seragam } \\ \text { AND } & \text { sulit bernafas } \\ \text { AND } & \text { diare berwarna kehijau-hijauan } \\ \text { THEN } & \text { penyakit Tetelo }\end{array}$

Setelah terbentuk tabel keputusan kemudian dibuat suatu pohon keputusan untuk membantu memudahkan cara penelusuran dalam mencapai kesimpulan, seperti gambar 1 . 
TELEMATIKA Vol. 06, No. 02, JANUARI $2010: 41$ - 48

Tabel 1. Hubungan Gejala dan Jenis Penyakit Ayam

\begin{tabular}{|c|c|c|c|c|c|c|c|c|c|c|c|c|c|c|c|c|c|}
\hline No & Gejala & $\begin{array}{l}\frac{g}{v} \\
\frac{\omega}{\omega} \\
\stackrel{\sigma}{\Sigma} \\
\dot{a} \\
\dot{a}\end{array}$ & 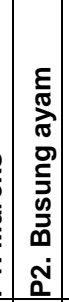 & 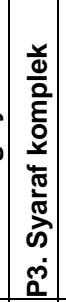 & 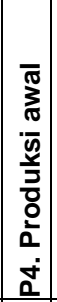 & 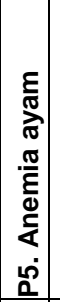 & 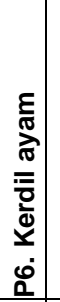 & 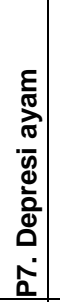 & 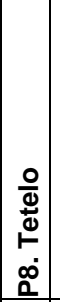 & 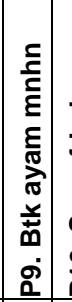 & 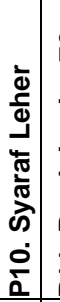 & 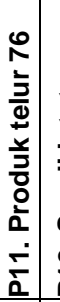 & 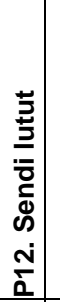 & 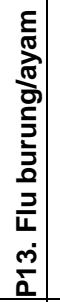 & 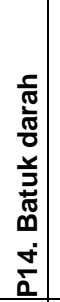 & 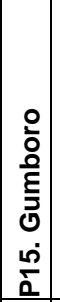 & 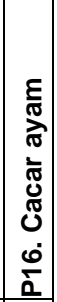 \\
\hline 1 & Jengger pucat, keriput serta kebiru-biruan & $x$ & $x$ & $x$ & $\mathrm{x}$ & & & & & & & & & & & & \\
\hline 2 & Pertumbuhan terhambat & & & & & $x$ & $x$ & $x$ & & & & & & & & & \\
\hline 3 & Produksi telur menurun & & & & & & & & $\mathrm{x}$ & $x$ & $x$ & $x$ & $x$ & & & & \\
\hline 4 & Keluar air mata & & & & & & & & & & & & & $\mathrm{x}$ & $x$ & & \\
\hline 5 & Batuk & & & & & & & & $x$ & $x$ & & & & $x$ & $x$ & & \\
\hline 6 & Ayam lesu serta lemah & $x$ & $x$ & & & & & & $x$ & $x$ & & & & & & $\mathrm{x}$ & \\
\hline 7 & Nafsu makan berkurang & $x$ & $x$ & & & & & $x$ & $x$ & $x$ & & & & & & & \\
\hline 8 & Kelumpuhan pada sayap dan kaki & $x$ & & $\mathrm{x}$ & & & & & $\mathrm{x}$ & & & & $x$ & & & & \\
\hline 9 & Malas bergerak dan sempoyongan & & & $x$ & & & & & & $\mathrm{x}$ & $x$ & & & & & $\mathrm{x}$ & \\
\hline 10 & Mengalami gejala katarak bahkan kebutaan & $x$ & & $x$ & & & & & & $\mathrm{x}$ & $x$ & & & & & & \\
\hline 11 & Bersin & & & & & & & & $x$ & $x$ & & & & $x$ & & & \\
\hline 12 & Berat telur turun dan ukuran tidak seragam & & & & & & & & $\mathrm{x}$ & $x$ & & $\mathrm{x}$ & & & & & \\
\hline 13 & Hati membesar & $x$ & & $x$ & & & & & & & & & & & & $\mathrm{x}$ & \\
\hline 14 & Ngorok & & & & & & & & & $x$ & & & & $\mathrm{x}$ & & & \\
\hline 15 & Kulit telur lunak & & & & & & & & & $x$ & & $x$ & & & & & \\
\hline 16 & Kulit telur terlalu kasar dan tidak rata & & & & & & & & & $x$ & & $x$ & & & & & \\
\hline 17 & Diare berwarna putih & & & & $\mathrm{x}$ & & & & & & & & & & & $\mathrm{x}$ & \\
\hline 18 & Sulit bernafas & & & & & & & & $x$ & & & & & & $\mathrm{x}$ & & \\
\hline 19 & Tumor dibawah kulit dan otot-otot & $\mathrm{x}$ & & $x$ & & & & & & & & & & & & & \\
\hline 20 & Bulu rontok & & & & & & & & & $\mathrm{x}$ & $x$ & & & & & & \\
\hline 21 & Kepala dan leher kaku & & & & & & & & & $\mathrm{x}$ & $x$ & & & & & & \\
\hline 22 & Terjadi radang pada rongga-rongga hidung & & & & & & & & & & & & & $\mathrm{x}$ & & & \\
\hline 23 & Diare & & & & & & & & & & & & & $x$ & & & \\
\hline 24 & $\begin{array}{l}\text { Kepala dan muka membengkak akibat bunting air atau gangguan } \\
\text { syaraf }\end{array}$ & & & & & & & & & & & & & $\mathrm{x}$ & & & \\
\hline 25 & Bintil-bintil cacar yang menonjol pada permukaan kulit dan kepala & & & & & & & & & & & & & & & & $\mathrm{x}$ \\
\hline 26 & Pembengkakan dari sinus hingga mata & & & & & & & & & & & & & & & & $\mathrm{x}$ \\
\hline 27 & Telur tidak berwarna & & & & & & & & & & & $x$ & & & & & \\
\hline 28 & Gejala pernafasan yang ringan & & & & & & & & & & $\mathrm{x}$ & $x$ & & & & & \\
\hline 29 & Kotoran semakin basah serta berwarna kehijau-hijaun & & & & & & & & & & & $x$ & & & & & \\
\hline 30 & Daerah sekitar kloaka kotor & & & & & & & & & & & & & & & $\mathrm{x}$ & \\
\hline 31 & Bursa fabricius membengkak 2-3 kali ukuran normal & & & & & & & & & & & & & & & $\mathrm{x}$ & \\
\hline 32 & Ginjal membengkak dengan warna putih keabu-abuan & & & & & & & & & & & & & & & $\mathrm{x}$ & \\
\hline 33 & Pendarahan pada urat daging & & & & & & & & & & & & & & & $\mathrm{x}$ & \\
\hline 34 & Kepucatan pada selaput lendir, jengger serta kaki & & & & & $x$ & & & & & & & & & & & \\
\hline 35 & Bila ayam mati akan lekas membusuk & & & & & $\mathrm{x}$ & & & & & & & & & & & \\
\hline 36 & Mengeluarkan lendir dari hidung dan mata & & & & & & & & & $x$ & & & & & & & \\
\hline 37 & Berkumpul di bawah pemanas & & & & & & & & & $x$ & & & & & & & \\
\hline 38 & Adanya getah radang (exudat) di rongga mulut & & & & & & & & & & & & & & $x$ & & \\
\hline 39 & Adanya getah radang (exudat) di batang tenggorokan & & & & & & & & & & & & & & $\mathrm{x}$ & & \\
\hline 40 & Tenggorokan seperti tersumbat & & & & & & & & & & & & & & $\mathrm{x}$ & & \\
\hline 41 & Paruh dan bulu kelihatan berdarah & & & & & & & & & & & & & & $\mathrm{x}$ & & \\
\hline 42 & Bulu sayap tumbuh tidak beraturan dan tidak normal & & & & & & $x$ & & & & & & & & & & \\
\hline 43 & Bulu seperti baling-baling & & & & & & $x$ & & & & & & & & & & \\
\hline 44 & Tungkai lemah & & & & & & $x$ & & & & & & & & & & \\
\hline 45 & Distensi bagian perut & & & & & & $x$ & & & & & & & & & & \\
\hline 46 & Perut membesar & & $\mathrm{x}$ & & & & & & & & & & & & & & \\
\hline 47 & Pembesaran pada tulang sayap dan kaki & & & $x$ & & & & & & & & & & & & & \\
\hline 48 & Penurunan berat badan & $x$ & & & & & & & & & & & & & & & \\
\hline 49 & Diare berwana kehijau-hijauan & & & & & & & & $x$ & & & & & & & & \\
\hline 50 & Tiba-tiba ayam berhenti bertelur & & & & $x$ & & & & & & & & & & & & \\
\hline 51 & Anak ayam depresi & & & & & & & $\mathrm{x}$ & & & & & & & & & \\
\hline 52 & Pembengkakan tendon diatas sendi lutut & & & & & & & & & & & & & & & & \\
\hline
\end{tabular}




\subsection{Mekanisme Inferensi}

Dalam penelitian ini sistem pelacakan yang dilakukan adalah menggunakan metode Forward chaining dengan teknik penelusuran Depth First Search. Misalnya terdapat suatu kesimpulan seperti pada tabel keputusan (Tabel 1) dan gambar pohon 1. Untuk kondisi $(3,5,6,7,8,11,12,18,49)$ benar, maka mesin inferensi mengambil kesimpulan penyakit Tetelo. Untuk kondisi $(3,9,10,20,21)$ benar, maka mesin inferensi mengambil kesimpulan penyakit Syaraf leher. Berikut dialog antara user dengan sistem

$\begin{array}{ll}\text { Sistem 1 Apakah jengger pucat, keriput serta kebiru-biruan }(\mathrm{y} / \mathrm{t}) ? & \text { User }: \mathrm{t} \\ \text { Sistem 2 Apakah pertumbuhan terhambat }(\mathrm{y} / \mathrm{t}) ? & \text { User }: \mathrm{t} \\ \text { Sistem 3. Apakah produksi telur menurun }(\mathrm{y} / \mathrm{t}) ? & \text { User }: \mathrm{y} \\ \text { Sistem 5. Apakah Batuk }(\mathrm{y} / \mathrm{t}) ? & \text { User }: \mathrm{t} \\ \text { Sistem 9. Apakah Malas bergerak dan sempoyongan }(\mathrm{y} / \mathrm{t}) ? & \text { User }: \mathrm{y} \\ \text { Sistem 10. Apakah mengalami gejala katarak bahkan kebutaan }(\mathrm{y} / \mathrm{t}) ? & \text { User }: \mathrm{y} \\ \text { Sistem 20. Apakah Bulu rontok }(\mathrm{y} / \mathrm{t}) ? & \text { User }: \mathrm{y} \\ \text { Sistem 21. Apakah kepala dan leher kaku }(\mathrm{y} / \mathrm{t}) ? & \text { User }: \mathrm{y}\end{array}$

Pada dialog diatas Langkah penelusuran dimulai dari pertanyaan 1 dijawab $\mathrm{t}=\mathrm{salah}$, penelusuran ke node 2 dijawab salah maka prolog mencari solusi ke node 3 dijawab $y=b e n a r$, diteruskan runut maju ke node dibawahnya yaitu 5 dijawab $\mathrm{t}=$ salah, prolog mencari solusi lacak runut balik kembali ke satu level di atasnya, yaitu ke node 3 , tetapi karena node 3 sudah pernah ditanyakan, pertanyaan sudah disimpan ke memori maka pertanyaan tersebut tidak dimunculkan kembali. Selanjutnya penelusuran dilanjutkan ke bagian anak cabang node lainnya yaitu node 9 dijawab = y benar, diteruskan runut maju ke node dibawahnya ke node 10 dijawab y=benar, dilanjutkan ke node 20 dijawab $y=$ benar, diteruskan ke node 21 dijawab $y=$ benar sampai kesimpulan penyakitnya adalah Syaraf leher. Berikut pohon penelusuran untuk penyakit syaraf leher.

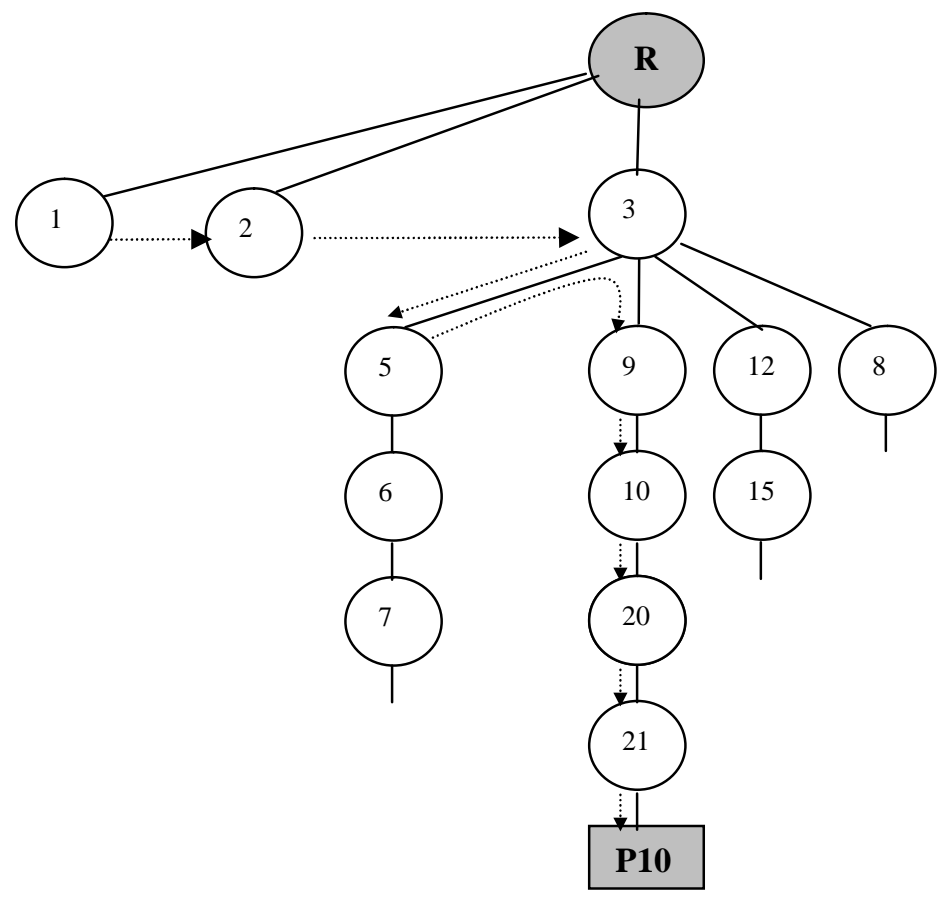

Gambar 1. Pohon Penelusuran Penyakit Syaraf Leher 


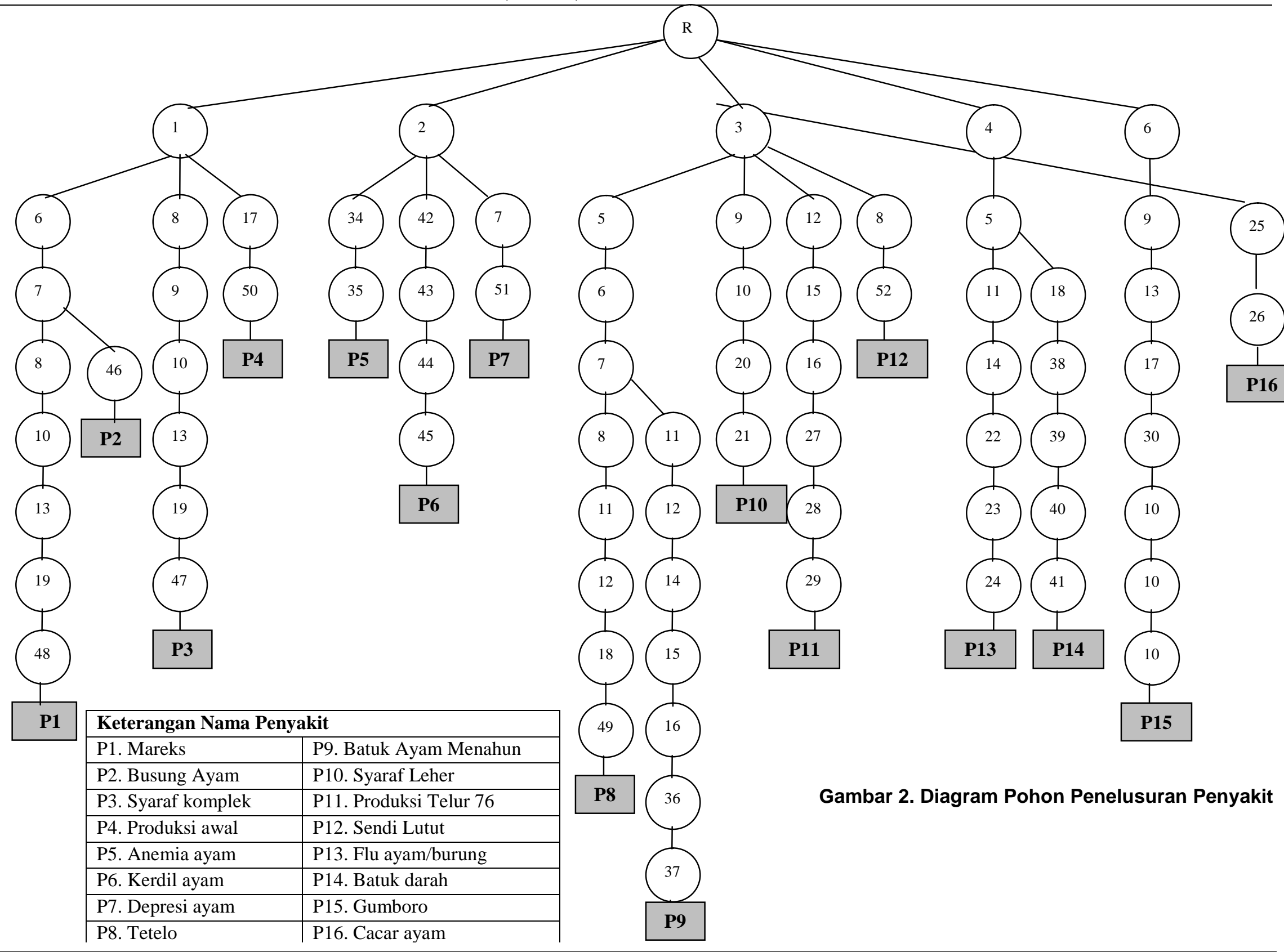




\section{Hasil Penelitian dan Pembahasan}

Telah diuji sebanyak 22 pengujian, seperti terdapat pada tabel 2 pada kolom pertanyaan dicatat nomor node saja dan pertanyaan yang muncul dicatat jawabannya berupa ' $y$ ' untuk true dan 't' untuk false. Kolom Rule merupakan node yang bernilai benar dan memenuhi syarat menuju kesimpulan.

Tabel 2. pengujian sistem

\begin{tabular}{|c|c|c|c|}
\hline $\begin{array}{l}\text { No } \\
\text { Uji }\end{array}$ & Pertanyaan $($ node $=$ jawaban $y / t)$ & Rule (node = 'y') & Output \\
\hline 1 & $\begin{array}{l}1=y, \quad 6=y, \quad 7=y, \quad 8=y, \quad 10=y, \quad 13=y, \quad 19=y, \\
48=y\end{array}$ & $1,6,7,8,10,13,19,48$ & P1 \\
\hline 2 & $1=y, 6=t, 8=t, 17=y, 50=y$ & $1,17,50$ & P4 \\
\hline 3 & $1=y, 6=t, 8=y, 9=y, 10=y, 13=y, 19=y, 47=y$ & $1,8,9,10,13,19,47$ & P3 \\
\hline 4 & $1=y, 6=y, 7=t, 8=t, 17=y, 50=y$ & $1,17,50$ & P4 \\
\hline 5 & $1=y, 6=t, 8=t, 17=t, 2=y, 34=y, 35=y$ & $2,34,35$ & P5 \\
\hline 6 & $1=y, 6=y, 7=y, 8=y, 10=t, 46=y$ & $1,6,7,46$ & $\mathbf{P 2}$ \\
\hline 7 & $1=t, 2=y, 34=y, 35=y$ & $2,34,35$ & P5 \\
\hline 8 & $1=t, 2=y, 34=t, 42=y, 43=y, 44=y, 45=y$ & $2,42,43,44,45$ & P6 \\
\hline 9 & $1=\mathrm{t}, 2=\mathrm{y}, 34=\mathrm{t}, 42=\mathrm{t}, 7=\mathrm{y}, 51=\mathrm{y}$ & $2,7,51$ & P7 \\
\hline 10 & $\begin{array}{l}1=t, 2=t, 3=y, 5=y, 6=y, 7=y, 8=y, 11=y, \\
12=y, 18=y, 49=y\end{array}$ & $\begin{array}{l}3,5,6,7,8,11,12,18 \\
49\end{array}$ & P8 \\
\hline 11 & $\begin{array}{l}1=\mathrm{t}, \quad 2=\mathrm{t}, 3=\mathrm{y}, 5=\mathrm{y}, \quad 6=\mathrm{y}, \quad 7=\mathrm{y}, \quad 8=\mathrm{t}, \quad 11=\mathrm{y}, \\
12=\mathrm{y}, 14=\mathrm{y}, 15=\mathrm{y}, 16=\mathrm{y}, 36=\mathrm{y}, 37=\mathrm{y}\end{array}$ & $\begin{array}{l}3,5,6,7,11,12,14,15 \\
16,36,37\end{array}$ & P9 \\
\hline 12 & $1=t, 2=t, 3=y, 5=t, 9=y, 10=y, 20=y, 21=y$ & $3,9,10,20,21$ & P10 \\
\hline 13 & $\begin{array}{l}1=t, 2=t, 3=y, 5=t, 9=t, 12=y, 15=y, 16=y, \\
27=y, 28=y, 29=y\end{array}$ & $3,12,15,16,27,28,29$ & P11 \\
\hline 14 & $1=t, 2=t, 3=y, 5=t, 9=t, 12=t, 8=y, 52=y$ & $3,8,52$ & P12 \\
\hline 15 & $\begin{array}{l}1=t, 2=t, \quad 3=y, \quad 5=y, 6=y, \quad 7=t, \quad 9=t, \quad 12=y, \\
15=t, 8=y, 52=y\end{array}$ & $3,8,52$ & P12 \\
\hline 16 & $\begin{array}{l}1=t, 2=t, 3=t, 4=y, 5=y, 11=y, 14=y, 22=y, \\
23=y, 24=y\end{array}$ & $4,5,11,14,22,23,24$ & P13 \\
\hline 17 & $\begin{array}{l}1=t, 2=t, 3=t, 4=y, 5=y, 11=t, 18=y, 39=y, \\
40=y, 41=y\end{array}$ & $4,5,18,38,39,40,41$ & P14 \\
\hline 18 & $\begin{array}{l}1=t, 2=t, 3=t, 4=t, 6=y, 9=y, 13=y, \quad 17=y, \\
30=y, 31=y, 32=y, 33=y\end{array}$ & $\begin{array}{l}6,9,13,17,30,31,32, \\
33\end{array}$ & P15 \\
\hline 19 & $\begin{array}{l}1=t, 2=t, 3=t, 4=t, 6=y, 9=y, 13=t, 25=y, \\
26=y\end{array}$ & 25,26 & P16 \\
\hline 20 & $1=t, 2=t, 3=t, 4=t, 6=t, 25=y, 26=y$ & 25,26 & P16 \\
\hline 21 & $\begin{array}{l}1=t, 2=t, 3=t, 4=y, 5=y, 11=y, 14=t, 18=t, \\
6=t, 25=t\end{array}$ & - & $\begin{array}{l}\text { Tidak } \\
\text { Ada }\end{array}$ \\
\hline 22 & $1=t, 2=t, 3=t, 4=t, 6=t, 25=t$ & - & $\begin{array}{c}\text { Tidak } \\
\text { ada }\end{array}$ \\
\hline
\end{tabular}

\begin{tabular}{|l|l|}
\hline \multicolumn{2}{|c|}{ Keterangan nama Penyakit } \\
\hline P1. Mareks & $\begin{array}{l}\text { P9. Batuk Ayam } \\
\text { Menahun }\end{array}$ \\
\hline P2. Busung Ayam & P10. Syaraf Leher \\
\hline P3. Syaraf komplek & P11. Produksi Telur 76 \\
\hline P4. Produksi awal & P12. Sendi Lutut \\
\hline P5. Anemia ayam & P13. Flu ayam/burung \\
\hline P6. Kerdil ayam & P14. Batuk darah \\
\hline P7. Depresi ayam & P15. Gumboro \\
\hline P8. Tetelo & P16. Cacar ayam \\
\hline
\end{tabular}




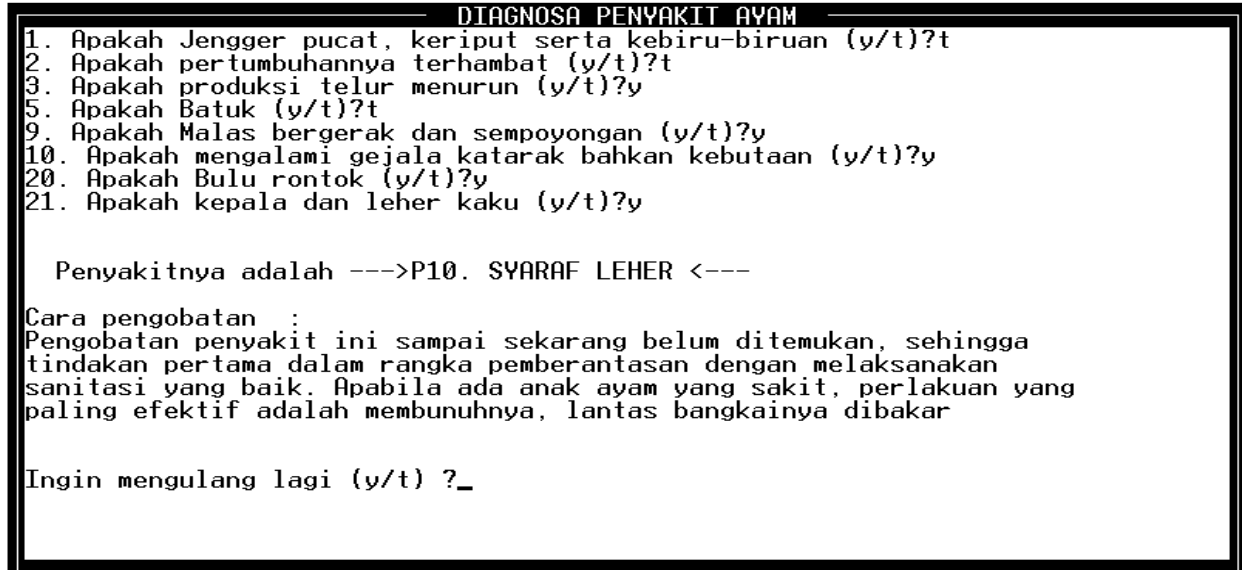

Gambar 3. Output Penyakit Syaraf Leher Berikut Cara Pengobatannya

Sistem akan menanyakan pada user dengan beberapa pertanyaan tentang gejala yang dialami ayam melalui suatu dialog. Adapun pemakai (user) cukup menjawab pertanyaan dengan 'ya' atau 'tidak' melalui keyboard Setiap pertanyaan di awal kalimat diberi nomor node untuk memudahkan pembacaan sekaligus untuk mengecek kebenaran metode Depth First Search. Metode ini dimulai dari simpul akar ke level yang lebih tinggi. Proses ini dilakukan terus hingga solusinya ditemukan atau jika menemui jalan buntu. Keuntungan metode ini disamping membutuhkan memori yang kecil, memungkinkan secara kebetulan, pencarian mendalam pertama dapat menemukan suatu solusi tanpa harus menguji lebih banyak lagi dalam ruang keadaan yang lain.

\section{Kesimpulan}

Sebagai kesimpulan dari seluruh kegiatan dalam penelitian ini dapat disampaikan sebagai berikut :

1. Telah berhasil dibangun perangkat lunak (sistem pakar) yang dapat digunakan untuk mendiagnosis penyakit pada ternak ayam khususnya penyakit ayam yang disebabkan oleh virus.

2. Output dari sistem pakar tersebut berupa jenis penyakit dan dilengkapi dengan cara pengobatannya.

\section{Daftar Pustaka}

Akoso Tri Budi, 1998, Kesehatan Unggas Panduan bagi Petugas Teknik, Penyuluh dan Peternak, Kanisius, Yogyakarta.

Yuwono Bambang, 2004, Sistem Pakar untuk diagnosis penyakit ayam dan cara pengobatannya, Tesis, UGM, Yogyakarta.

Giarratano, J. \& Gary R., 1994, Expert Systems Principles and Programming, PWS Publishing Company, Boston.

Harmon, P. and King, David, 1985, Expert System : Artificial Intelligent In Bussiness, John Wiley \& Sons Inc, New York.

Kusumadewi, Sri, 2003, Artificial Intelligence (Teknik dan Aplikasinya), Graha Ilmu, Yogyakarta, pp 109-113

Murtidjo Agus Bambang, 1992, Pengendalian Hama dan Penyakit Ayam, Kanisius, Yogyakarta.

Turban, Efraim, 1995, Decision Support System and Expert System, $4^{\text {th }}$ ed., Prentice-Hall, Inc., New Jersey, pp 472-679 